\title{
THE VISIT OF ATHENA TO ACHILLES IN ILIAD I
}

\begin{abstract}
Athena's intervention in $\mathrm{Il}$. I is to be understood literally, not in a metaphorical or symbolic sense. The reasons for her intervention are explained by the structure of the first book and of the poem as a whole.
\end{abstract}

Each of two gods applies a powerful impulse in Il. I so as to guide the poem along the course desired by the narrator. First the action of Apollo leads directly to Agamemnon's quarrel with Achilles. This quarrel, in its turn, results in the promise made by Zeus to direct the ensuing action in a certain way. The quarrel itself dominates the first half of the book, and its consequences are worked out in the second half. The quarrel receives one check from Athena, and another from Nestor; but after each check the quarrel continues. Athena expressly tells Achilles to pursue it, but in words only, while Nestor cannot reconcile the two heroes, and the quarrel is simply allowed to die away with the dissolution of the assembly (I 305).

For Achilles the time for words comes to an end at 187. Agamemnon's whole attitude, and specifically his threat to take from Achilles the prize duly allotted him, are intolerable to Achilles. He now thinks of resorting to violence, and would have done so but for Athena's appearance (188-221).

This is the first of many confrontations in the Iliad between a hero and his protecting divinity. From time to time throughout the poem we have evidence of an identity of interests and an intimate relationship between Achilles and Athena. Their collaboration in the defeat of Hector in XXII is only the logical outcome of this identity and this relationship. Yet for a number of years it has been felt that the scene between them in I presents certain peculiarities, or at any rate certain significant features, which make it worthy of close attention. Both chronologically and in order of importance, Nilsson's contribution should 
be considered first ${ }^{\prime}$. The originality and powerful argumentation of this paper make it fully worthy of its great author. Two of the many themes developed by Nilsson have a special bearing on the scene between Athena and Achilles.

First is the statement that the type of divine apparatus, or divine machinery, seen at work in the Homeric poems is a purely literary creation; there is nothing "spiritual» about it, nor has it anything to do with feelings of a genuinely religious character ${ }^{2}$. The second of Nilsson's themes directly relevant here concerns the "double motivation", whereby the actions, and even the thoughts, of gods and men may proceed along parallel lines ${ }^{3}$. Nilsson judges from a number of instances that the intervention by a divinity presents a parallel to the innermost emotions of a human being. As a typical example of this double motivation, Nilsson chooses our passage ${ }^{4}$. He holds that the conduct and speeches of Achilles and Agamemnon are adequately explained according to the terms of human psychology: hence the appearance of Athena is completely superfluous. Despite the extreme provocation offered him, Achilles (says Nilsson) pauses before doing violence to the king. He draws his sword, but a moment's reflexion allows reason to gain the upper hand; he replaces the sword and allows his anger to express itself in words. All of this, according to Nilsson, is fully comprehensible without the necessity of a divine manifestation.

The most distinguished intellectual descendant of Nilsson, and one who fully acknowledges his inheritance, is of course Dodds. His own interpretation of the scene with Achilles and Athena is based on that of Nilsson, as may be seen from his well-known remarks:

How much more vivid than a mere inward monition is the famous scene in Iliad I where Athena plucks Achilles by the hair and warns him not to strike Agamemnon! But she is visible to Achilles alone: "none of the others saw her". That is a plain hint that she is the projection, the pictorial expression, of an inward monition.

Then Dodds passes beyond the point reached by Nilsson and suggests «that in general the inward monition, or the sudden unaccoun-

1 M. P. Nilsson, "Götter und Psychologie bei Homer», Opuscula Selecta, I, 1951, pp. 355-91 (AfR 22, 1923-4, pp. 363-90).

2 Op. cit., p. 364. Cf. P. Chantraine, Entretiens Hardt, I, 1954, pp. 47-79.

3 Op. cit., p. 359.

4 Op. cit., pp. 368-70. 
table feeling of power, or the sudden unaccountable loss of judgement, is the germ out of which the divine machinery developed ${ }^{5} "$.

Although I am not aware that Dodds' theory concerning the origin of the divine machinery has received much support, his interpretation of the Achilles-Athena scene itself remains influential to our own day, as may be seen from G.S. Kirk's treatment in his recent commentary (1985).

Before examining the view which regards Athena in our scene as the mere incarnation of Achilles' own judgement, I must mention the somewhat different approach taken by Bruno Snell. True to his belief that the Homeric heroes did not possess a completely integrated personality, Snell makes the following comment on Achilles' restraint by Athena:

At the very beginning of the Iliad, when the quarrel between Agamemnon and Achilles has flared up. Agamemnon demands that Achilles should give up Briseis and provokes him so seriously that Achilles seizes his sword and considers whether to draw it against Agamemnon. At this moment Athena appears (and appears, as is expressly stated, to Achilles alone); she restrains him, and warns him not to give way to his anger; in the end it will be to his advantage if he restrains himself now. Forthwith Achilles complies with the warning of the goddess and thrusts back his sword into its scabbard. The poet had no need of the "divine apparatus" in this passage: Achilles simply controls himself, and the fact that he does not rush upon Agamemnon would have been explicable from his own intellectual process. So far as we are concerned, Athena's intervention rather confuses the motivation than makes it plausible. But for Homer the deity is necessary at this juncture. We might have substituted a "decision" by Achilles: his own deliberation, and his own act. But in Homer man does not yet feel himself the author of his own decisions: that comes about for the first time in tragedy. When Homeric man determines on a certain course after due deliberation, he feels that this course has been prescribed by the gods ${ }^{6}$.

From their differing points of view, Nilsson, Snell, and Dodds have acutely analysed Achilles' dilemma in modern terms. In so doing they have stated, and even somewhat over-stated, the difference between Homeric and modern man. They observe, quite rightly, that Homer's heroes often attribute to some external force what cannot be explained obviously in terms of their own intellect or their own personality. Homeric man tends to say that a specific god, or some unknown god, has endowed him with some special quality, such as battle-fury ( $\left.\mu \varepsilon^{\prime} v o s\right)$ or fleetness of foot; alternatively that a god has sent upon him

${ }^{5}$ E. R. Dodds, The Greeks and the Irrational, 1951, p. 14.

${ }^{6}$ B. Snell, Die Entdeckung des Geistes, 1980, pp. 35-6 (my translation). 
some overmastering power, such as ăr $\eta^{7}$. If such expressions betray a "primitive" state of mind, then we are assuredly still at the "primitive" stage. We say «I don't know what come over me». And some of us make the same assumptions about the "divine apparatus" that the heroes made; for do we not hear wit was Providence that brought it about», and similar expressions? Language of this kind does not, of course, imply that we are incapable of reaching decisions by ourselves; and here again, as we shall see presently, there is not such a wide gap as is often supposed between the "Homeric» attitude and our own.

Returning to the Achilles-Athena scene, we may ask how the goddess' presence can be "superfluous» when the poet, or $a$ poet, thought it necessary to the realization of the scene, and introduced it in no casual or off-hand manner but with a force and vividness which must impress themselves on every listener or reader. This fact, which has an intimate connexion with the dramatic stucture of $I l$. I, receives too little consideration from Dodds or Snell. These writers do not ask wh the scene has been shaped in the way that it has, and especially why Athena is brought in at all. Yet this question should be regarded as a fundamental one by anybody seeking a correct interpretation of our scene. In Homeric poetry at large, it is quite rare for a divinity to impose a decision upon one of the human participants; and we might reasonably surmise that the divinity does so at a critical moment, or to fulfil some special purpose of the poet's own. It is, of course, not at all uncommon for a hero to be shown in doubt how best to act in a given contingency. "Then", according to the usual formulation, "this appeared to him more advantageous ( $\kappa \varepsilon \rho \delta(o v) »$. No god descends from Olympus to help him form his decision; still less is any god needed to «embody" that decision. In his failure to take account of the uniqueness of the AchillesAthena scene as an example of the decision-making process in Homer, Dodds takes a false turning. For it seems plain that Homeric man was perfectly able to reach a decision by himself and then to act upon it. Compelling arguments in support of this view have been advanced by Lesky ${ }^{8}$, and they need not be repeated here; at any rate, they dispose finally of the notion that human will as such does not exist for Homer and that the gods have a hand in shaping all decisions taken by the heroes.

It is the more strange that Snell did not draw an explicit contrast

7 Very well put by Dodds, op. cit., pp. 2-11.

${ }^{8}$ A. Lesky, Göttliche und menschliche Motivation im homerischen Epos, SB Heidelberg 1961: 4. Reply by Snell, op. cit., pp. 286-7. 
between the Achilles-Athena scene and the prevailing type of Homeric decision-making because later in his book, when he again discussed our scene, he actually stated that «the formula 'it seemed more advantageous to him' often ends Homer's description of a man deliberating with himself ${ }^{9}$. A perfectly true statement; but, if it is true, we cannot accept as being also true Snell's previous observation that «the deity is necessary at this point».

As is generally known, Snell had a particular reason for denying to Homeric man the capacity of forming decisions, or even judgements. He cannot come to decisions, according to Snell, because the very notion of a discrete human personality is unknown to Homer; and this incapacity is demonstrable in a number of ways, but especially by the absence from the Homeric vocabulary of a word meaning 'the human body' ${ }^{10}$. It is undeniably a remarkable fact, and one which Snell investigated more extensively than anyone else, that while Homer often refers to parts of the body such as $\mu \dot{\varepsilon} \lambda \varepsilon a$, үuĩa, $\rho \varepsilon \vartheta \varepsilon a$, and yoúvara he has no term for the body in its totality. A further feature of the epic language adduced by Snell in support of his contention is that Homer re-

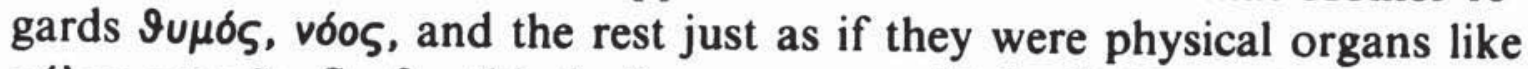
$\mu \varepsilon \hat{\varepsilon} \varepsilon a$ or yuĩa. So for this further reason, said Snell, Homeric man cannot be said truly to "reflect» within himself; all he can do, apparently, is to engage in a dialogue with his own 9upós ${ }^{\prime \prime}$. These phenomena of Homeric diction point to a concept of the body quite different from our own but, as Lesky observed, they are not peculiar to Homer, or even to Greek literature ${ }^{12}$.

Snell's arguments are, in fact, vulnerable at several points, a few of which may be considered here. We have to agree that Homer has no word for the human body in its totality. It would, however, be rash to conclude from this fact, without examining other facets of the Homeric language, that the epic is completely without resources for referring to the whole man and to his capacity for making decisions - and making them, on many occasions, without the intervention of any god. Certain turns of phrase seem to be especially significant.

First we may notice some occurrences of aúrós. This word, when used in the nominative, is always strongly emphatic in Homeric, as in later, Greek; but Homer can use aúrós to do more than merely convey

9 Op. cit., p. 153.

${ }^{10}$ Op. cit., pp. 16-25.

"On this formula cf. R. W. Sharples, "But why has my spirit spoken with me thus?': Homeric decision-making", $G \& R$ 30, 1983, pp. 1-7.

12 Op. cit. pp. 9-10. 
emphasis: it may actually indicate that a hero is acting according to his own arbitrary, irresponsible will, without reference to any man or any god, and in a way which implies that he has previously reached a decision so to act. Let us consider an incident, trivial perhaps to us but certainly not to the parties involved, at the end of the chariot-race in Il. XXIII. Antilochus "apologizes» to Menelaus in the only way known to the Homeric hero, namely by making material recompense, here in the shape of the mare he has won as his prize: iัmกov $\delta \dot{\varepsilon}$ тol aủròs $\delta \dot{\omega} \sigma \omega$ Ti்v áó $\mu \eta v$ (XXIII 591-592). What does aútós mean in this context? Not simply 'I myself' (since no one else is in question), but 'I by my own will'; that is to say, 'I do not have to do it, but I choose to do it' or, in other words, 'I have decided to do it'.

A similar use is found in the last Book, when Priam is pressing Achilles to accept ransom for Hector's body. Achilles replies: $\mu \eta \kappa \varepsilon \dot{\varepsilon} t$ vũv

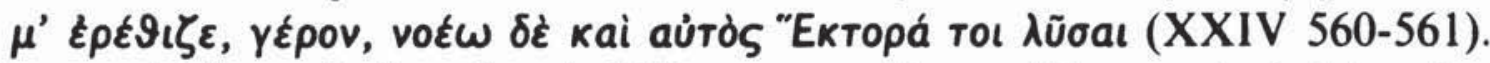
It would be pointless for Achilles to say 'I myself' am minded to give back Hector. No, he means 'it is my decision, my will to do so'.

Equally unambiguous is the sense of aủrós at I 355-356:

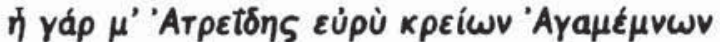

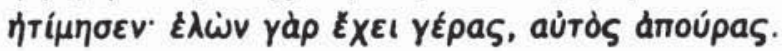

Achilles is complaining to Thetis of Agamemnon's conduct. How could aùrós here mean 'he himself? Not only is it unthinkable that the great king should go in person to Achilles' hut on such an errand, but we have just been told explicitly that he sent his heralds to fetch Briseis. Hence we see that this aúrós too must mean 'by his own arbitrary act', as a result of the decision he announced earlier (I 185) ${ }^{13}$.

Another term which Homer may use to indicate 'will' rather than

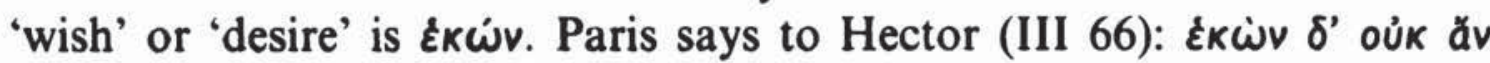
TIS Ė入ıто, 'of his own will no one could win (the gifts of the gods)' that is to say 'however much he would like to do so' ${ }^{14}$. Noteworthy too is the use of $\dot{\varepsilon} \kappa \dot{\omega} v$ at IV 43, where Zeus is adressing Hera: $\dot{\varepsilon} \gamma \dot{\omega}$ ooi

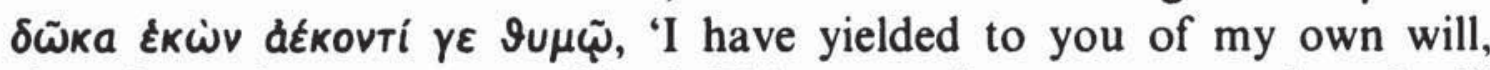
though my heart was unwilling'. This use points to an exercise of will which over-rules natural inclination. And Hector's reproach to Paris (VI 523) shows clearly that $\dot{\varepsilon} \kappa \dot{\omega} v$ is not synonymous with $\dot{\varepsilon} \vartheta \dot{\varepsilon} \lambda \omega v$ : $\dot{\varepsilon} \kappa \dot{\omega} v$

13 These observations make it unnecessary to see in II. I 356 the re-working of an earlier version in which Agamemnon did go in person, as is postulated by G. P. Goold, ICS 2, 1977, p. 33.

14 Cf. W. Krause, Aus Allem Eines, 1984, p. 18. 
$\mu \varepsilon \vartheta เ \varepsilon i \varsigma \varsigma$ TE каi oủk $\varepsilon \vartheta \varepsilon \lambda \varepsilon เ \varsigma$, "of your own will you are slack and do not care' ${ }^{15}$.

Further types of Homeric locution make it clear that the epic poets had a concept of the whole man. It is not easy to see how a hero could be said to address his own $9 u \mu \delta \varsigma$ if no complete person were involved ${ }^{16}$. Then there is the familiar type of expression indicating the organ of a hero which is affected by some external action, often one initiated by a god. If it were really the case that Homer is unable to refer to the whole man, we should hear simply of the part affected. But much the commonest way of describing an effect upon a person's organ is to use first a word applicable to the whole man, whether a proper name or a pronoun, and then a word in the dative or locative indicating the part especially involved. A few striking instances will suffice to exemplify the type:

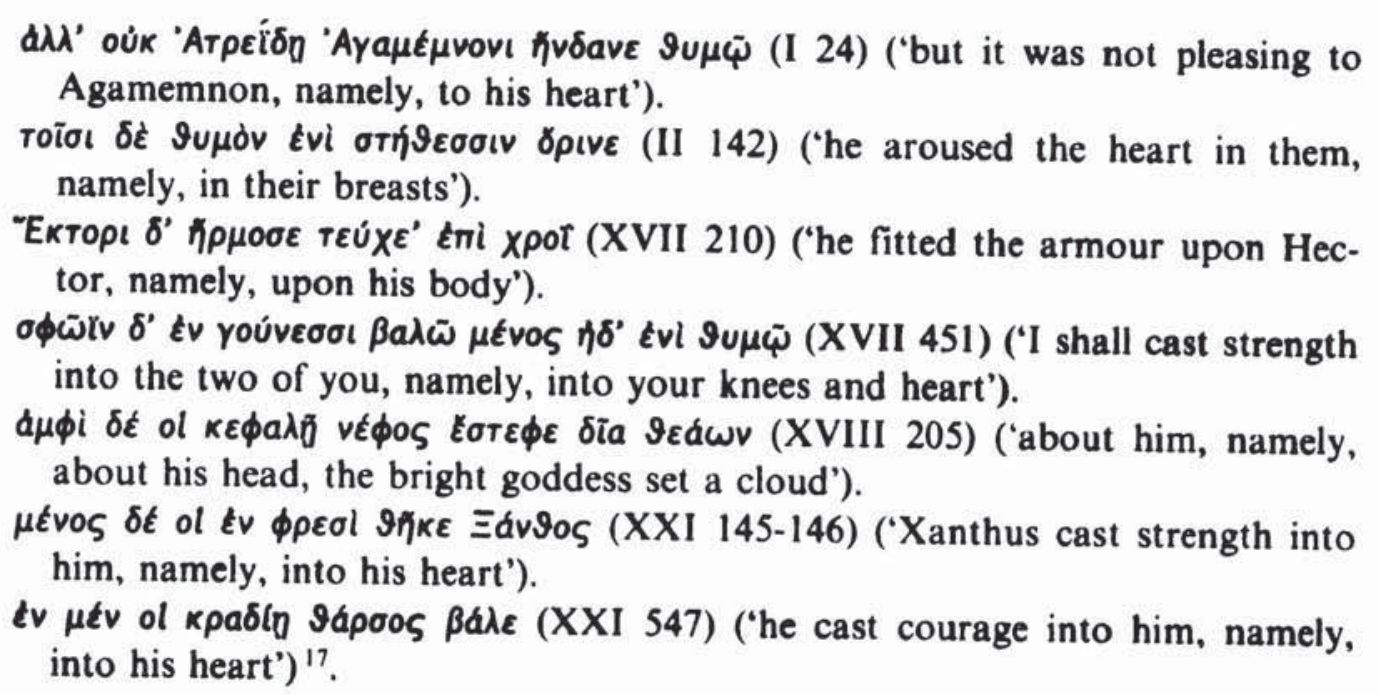

Such expressions could hardly have grown up, still less have become so common and so stereotyped, in a poetical tradition which did not recognize the totality of the human person or the possibility of drawing a contrast between the whole person and one of his organs.

It seems certain, then, that the poets of the epic tradition did some-

is A very similar expression occurs at $O d$. IV 372.

${ }^{16}$ Lesky, op. cit., p. 9.

17 It is only because aúró means 'the whole person' in contrast to individual organs that the description of Odysseus as he lies sleepless can take the following

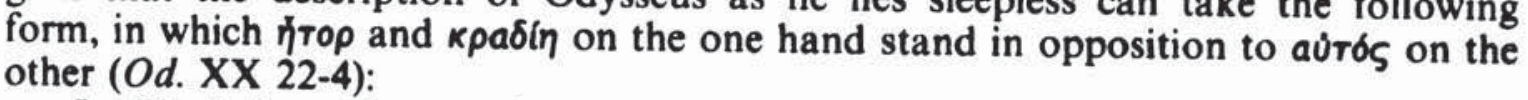

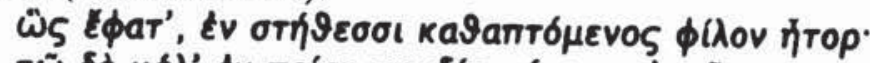

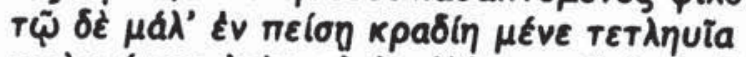

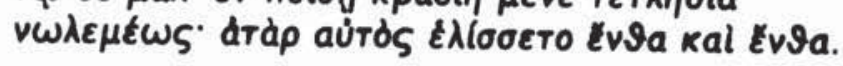


times speak of the human person as a whole, even though they undoubtedly visualized both the mental and the emotional processes of human beings in a far more concrete way than we do. We see such processes in psychological terms; Homer saw them in physical terms. But we are not entitled to wrench from their context the Homeric outlook and the Homeric vocabulary, and then transplant them to our world. When Homer describes the sudden appearance of Athena, who plucks Achilles by the hair, he means exactly what he says. Athena's intervention is not to be equated, as Dodds suggests, with a "mere inward monition" on the part of Achilles. If the poets had wanted to describe an «inward monition", they had ample resources for doing so. We are to understand Athena's action quite literally ${ }^{18}$. The motive for so striking an intervention by the goddess will be considered later. Meanwhile a little should be said about a particular aspect of the scene dwelt upon by Dodds. He contends that Athena's appearing to Achilles alone is an indication of the essentially psychological nature of the whole scene. This is not the case. The invisibility of the goddess to all except Achilles is absolutely necessary, given the situation. Athena is intent on maintaining the status of Achilles, which has been grievously undermined by Agamemnon's threat. For this reason she assures him that if he yields to her on this occasion he will later have his reward: a reward in the form of material treasure, just as we expect in Homer. But Athena would actually have diminished Achilles' prestige, and even made him a ludicrous figure, if in full view of everyone she had pulled his hair and so bent him to her will. So in the Odyssey, when Athena transforms Odysseus before he is recognized by Telemachus, she shows herself to Odysseus alone. Her invisibility on this occasion also is justified by the context, and by nothing else; the recognition would have lost its effect if Telemachus had witnessed the goddess' action and heard her words in advance: as the poet himself remarks, 'the gods by no means manifest themselves clearly to everyone' (Od. XVI 161) ${ }^{19}$. Nor do they; but Odysseus, like Achilles, is a privileged recipient of the divine favour.

Assuming, as I think we must, the reality of Athena's intervention

18 The danger of misrepresentation if early Greek poetry is interpreted without regard to its own cultural assumptions may be illustrated from Hesiod: cf. K. Latte, Kleine Schriften, 1968, p. 62.

${ }_{19}$ Nilsson, op. cit. p. 367 sees in the Odyssey passage the use of a "folk-lore motifn; but to my mind it is (just like Athena's appearance in II. I part of the stockin-trade on the epic poet, to be deployed when convenient. A much more obvious reflexion of folk-lore is to be found in Il. V 844-5. where Athena puts on the "cap of Hades' (i.e. invisibility) so as to avoid being seen by Ares: cf. P. Thieme in Indogermanische Dichtersprache, Wege der Forschung CLXV, 1968, p. 140. 
in precisely the terms described by Homer, we must next ask why her intervention was necessary at all, since Homeric man was fully able to envisage alternative courses of conduct, and to make a choice between them. Two reasons may be advanced for the poet's preferring, on this occasion, to invoke the actual presence of the deity. One reason is connected with the immediate requirements of the scene itself; the other with the economy of the whole poem, and especially of Il. I.

The very nature of the quarrel between Achilles and Agamemnon, and the status of the participants, allow a simple explanation to be put forward for Athena's intervention. This is the explanation of Wilamowitz $^{20}$. He argues that after Agamemnon's final, intolerable threat, violence seems inevitable. But, since poet and audience alike know that violence did not in fact ensue, someone has to mediate between the two heroes. They will not accept the mediation of any of the other kings, such as Odysseus or Nestor; consequently the intervention of some higher power becomes necessary ${ }^{21}$.

Such an explanation, though not seriously mistaken, cannot be regarded as adequate because it does not account for, and does not even try to account for, the peculiar structure of the narrative, whereby a hero reaches a decision but is prevented by the sudden appearance of a deity from putting his decision into effect. To my mind, a satisfactory account of the matter is given by Tsagarakis ${ }^{22}$. Although, as he rightly holds, it is open to Homeric man to reach his decisions and act upon them by himself, there arise situations in which he must not be allowed to do so. Regarding our scene in purely Homeric terms, we have to say that Athena's presence is required so as to place a check on the super-

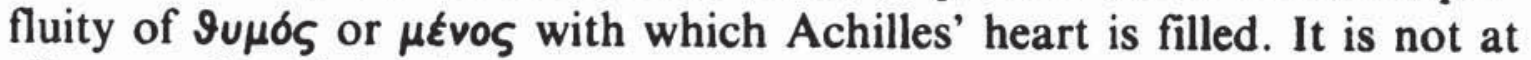
all, as rationalizing interpreters like Nilsson and his successors would have us believe, that after consideration Achilles' reason asserts itself and he realizes the disastrous consequences if he were to strike Agamemnon dead. That is not even an accurate account of the text. What we read in Homer is that after consideration Achilles started to draw his sword from its scabbard, so indicating that he had already reached his decision, namely to attack Agamemnon ${ }^{23}$. So it can-

${ }^{20}$ Die Ilias und Homer, 1916, p. 249.

${ }^{21}$ H. Erbse, Untersuchungen zur Funktion der Götter im homerischen Epos, 1986, p. 139 argues along similar lines.

${ }^{22}$ O. Tsagarakis, «Die Epiphanie Athenes im A der Ilias: Psychologie oder Religion?", Gymnasium 87, 1980, pp. 57-80.

${ }^{23}$ Details in H. Fränkel, Dichtung und Philosophie des frühen Griechentums, $1962_{2}$, pp. $75-6$. 
not be Achilles' "reason» that asserts itself; nor does "reason» play a significant part in motivating any of his actions - not, at least, until we reach the funeral-games and Achilles assumes the part of disinterested umpire. On the present occasion, in $\mathrm{Il}$. I, when the protecting goddesses see that Achilles has made his choice and is bent on a disastrous course (disastrous, that is to say, to the Achaean cause, not necessarily for himself), they decide to intervene. And how does Athena effect her mission? Not by forbidding Achilles to embrace the more violent course, but in a way which reveals her deep knowledge of the acquisitive character of Homeric man: she points out to him the material advantages to be gained by choosing the less violent course ${ }^{24}$.

In general, then, it seems correct to say that a hero can reach decisions by himself, and will be left to give effect to his own decisions when his action does not jeopardize the ordained course of events. Otherwise the divine powers will feel impelled to take a hand. The truth of these statements may be illustrated by referring to two episodes of Odysseus' career in the Iliad.

In Il. XI, when first Agamemnon and then Diomedes have been wounded and have retired from the battlefield, Odysseus remains alone to contemplate the options open to him. This he does in the accustomed Homeric manner. There are arguments in favour of flight, but the arguments for holding his ground are stronger, for this is the conduct appropriate to an apıros like himself ${ }^{25}$. No divine intervention occurs, nor is one necessary: Odysseus simply reaches his own decision by evaluating the alternatives. The decision he takes is certainly of interest to us, in that it displays so clearly the attitude of a hero towards his duties ${ }^{26}$; but it makes no profound difference to the plot of the poem whether Odysseus stays or runs away - and it is above all for this reason that the gods allow events to take their course.

The scene in Il. II in which Odysseus plays an important part is of a different character, and has a different outcome. Relying on the message brought him by the deceptive dream, Agamemnon has made an eloquent speech to the Achaeans, in which he urges them to take their ships back home. At once they begin streaming to the shore, and cannot wait to launch the ships. A serious crisis which threatens the whole expedition is now imminent. Hera is aware of it, and calls upon Athena to take immediate action (II 156-165). Athena darts down to earth and

${ }^{24}$ Cf. Snell, loc. cit.

${ }^{25}$ Cf. Sharples, op. cit.

${ }^{26}$ Compare the reflexion of Menelaus in Il. XVII 91-105 and that of Hector in Il. XXII 99-130. 
finds Odysseus standing by his ship, sadly perplexed. He is in the grip of äxos, just like Achilles in our scene. Athena repeats to him the instructions of Hera, namely that he should approach the Achaeans one by one and dissuade them from putting to sea. It is easy to see why divine intervention is called for here, as it is not called for in Il. XI. Agamemnon's words in II are so much to the liking of his listeners that only a hero under divine inspiration would be able to arrest their headlong flight.

When we observe the same coalition of goddesses at work here as in the Achilles-Athena scene in Il. I, we may be able to suggest a motive for that scene which brings it into the context of the whole Iliad. The plan of Zeus, as set out in I, forms the framework of events up to Achilles' renunciation of his wrath in XIX. It is a loose framework, and within it heroes and gods sometimes embark on activities which are out of harmony, or actually in conflict, with Zeus' overall plan. Personal antagonisms between gods, the partiality of Zeus for his daughter Athena, his obligations towards Thetis, his deception by Hera in Il. XIV, and the adjustment of the gods' will to the decrees of fate: all these add to the complexity of the situation, and make it impossible to see the plot simply in terms of hero against hero, hero against god, god against god $^{27}$. But, leaving aside deities like Aphrodite and Poseidon, who make some decisive, but only sporadic, interventions, we witness a stark confrontation between two divine powers: Apollo standing out as champion of Troy and especially of Hector; Hera and Athena as champions of the Achaeans, and especially of Achilles, Diomedes, and Odysseus.

There are many respects in which Il. I displays the mastery with which it is often credited. The causes of the ensuing strife are powerfully set out. Agamemnon, Achilles, and Nestor reveal their respective characters, so giving us, even at this early stage, a precious insight into the nature of the Homeric hero. But above and beyond all these revelations, essential though they are, is the extraordinary relationship which obtains in Homeric poetry between gods and men. The relationship takes on many aspects, which will emerge in the course of the poem but which it would be inappropriate to explore in detail in this book. What Homer does, besides showing the formation of Zeus' plan and the reasons for it, is to offer a kind of paradigm of the divine operations which are largely, though not entirely, to control events in the remainder of the poem. And, quite naturally, the gods we first see in action

${ }^{27}$ Cf. K. Reinhardt, Die Ilias und ihr Dichter, 1961, pp. 24-5. 
are the ones whose rivalry will colour the whole epic. Hardly has the poem begun than Apollo appears in answer to Chryses' prayer: an appearance with the properties of terror and wonder that make it a true epiphany ${ }^{28}$. As a counterpoise to this lethal display of force by the mighty god, his opponents Hera and Athena make a decisive intervention on their part: they prevent an occurrence which could only ruin the interests of their beloved Achaeans.

Finally I revert to the title of Tsagarakis' paper (n. 22). The appearance of Athena in $I l$. I is not to be explained in psychological terms, since a psychological process could have been represented as such without divine manifestations in the Old Testament to realize that religious feeling has nothing to do with it. The goddess, or rather the two goddesses, are made to intervene for purely literary, or dramatic, reasons: to damp down Achilles' excessive ardour and so to avoid disaster. If we ask, further, why the se goddesses in particular were chosen to check Achilles, the answer may again be couched in literary terms: their intervention, together with that of Apollo, enables us to see at work the two great rival forces which, within the terms of Zeus' dispensation, favour respectively the Achaean and the Trojan side.

J. T. HOOKER

${ }^{28}$ Cf. W. Kullmann, Das Wirken der Götter in der Ilias, 1956, pp. 83-111; B. C. Dietrich, "Divine epiphanies in Homer», Numen 30, 1983, pp. 53-79; P. Pucci, «Epifanie testuali nell' Iliaden, SIFC 78, 1985, pp. 170-83. 